\title{
Effect of low or high stress in pre-slaughter handling on pig carcass and meat quality
}

\author{
Louise Manha Peres ${ }^{1}$, Ana Maria Bridi ${ }^{1}$, Caio Abércio da Silva ${ }^{1}$, Nayara Andreo ${ }^{1}$, Marina Avena \\ Tarsitano ${ }^{1}$, Evelyn Leticia Tazima Stivaletti ${ }^{1}$
}

${ }^{1}$ Universidade Estadual de Londrina, Londrina, PR, Brasil.

ABSTRACT - The objective of this study was to evaluate the consequences of low or high stress during pre-slaughter handling of pigs on their carcass and meat quality. Forty-four animals of a commercial lineage, with an average weight of $107.23 \pm 5.23 \mathrm{~kg}$, were used. At lairage the animals were randomly divided into two groups, the least and the most stressed. At slaughter, during bleeding, blood samples were collected for later cortisol and lactate tests. Forty-five minutes after slaughter the initial $\mathrm{pH}$ of th carcasses was measured and samples of the semitendinosus muscle were collected for R-value calculation. After 24 hours of cooling, the final $\mathrm{pH}$ was measured, damage scores were assessed and samples of the longissimus dorsi muscle were collected to evaluate drip loss, liquid loss from defrosting and cooking, shear force, lipid oxidation, and color. The results were evaluated by analysis of variance and the means were compared by Tukey's test. It was found that cortisol, lactate and R-value were lower and initial pH was higher for the least stressed animals, whereas the other parameters were not significantly affected. Thus, low stress in the pre-slaughter handling of pigs is effective in reducing stress and carcass damage, but has no effect on meat quality.

Key Words: carcass damage score, cortisol, lactate, lipid oxidation, $\mathrm{pH}, \mathrm{R}$-value

\section{Introduction}

The handling of animals for slaughter is composed of a series of procedures that are quite uncommon and therefore stressful for them. Pre-slaughter handling consists of handling the animals both on the farm and during the transport (loading/displacement/landing), at lairage, and finally on their way to be stunned and slaughtered. Hence, these activities should be well planned and professionally carried out to minimize stress (Costa et al., 2002).

Meat quality has a direct association with preslaughter handling and even animals treated under top animal-welfar conditions may have their meat quality compromised if handling is not appropriately performed (Bonfim, 2003).

Incorrect pre-slaughter handling may cause carcasses to develop abnormalities such as PSE (pale, soft, exudative) or DFD (dark, firm, dry) meat (Kauffman et al., 1978).

In order to enhance the welfare of animal pre-slaughter, reduce stress and consequently increase meat quality, both

Received July 82013 and accepted March 28, 2014.

Corresponding author: louise_mp@zootecnista.com.br

http://dx.doi.org/10.1590/S1516-35982014000700004

Copyright $@ 2014$ Sociedade Brasileira de Zootecnia. This is an Open Access article distributed under the terms of the Creative Commons Attribution Non-Commercial License, which permits unrestricted non-commercial use, distribution, and reproduction in any medium, provided the original work is properly cited. producers and meat packers have been investing in new handling techniques as well as appropriate equipments and facilities (Goettems, 2011).

The objective of this study was to evaluate the effect of the use of handling board on stress parameters and pork quality by evaluating low- and high-stress-treatment groups.

\section{Material and Methods}

Forty-four barrows, with an average weight of $107.23 \pm 5.23 \mathrm{~kg}$, were slaughtered. The treatments were set in a completely randomized design. To evaluate carcass and meat parameters, each animal was considered an experimental unit.

Pre-slaughter handling started on the farm. The animals were only allowed to consume drinking water until slaughter, as the feed had been withdrawn seven hours before boarding time and the slaughter occurred 14 hours later, totaling 21 hours of fasting.

The animals were handled into the truck with the aid of a handling board and transported to the slaughterhouse (22 km away from the experiment site) the afternoon before the slaughter because of the milder temperatures. The abovementioned handling board was made of hard plastic, weighing $7.5 \mathrm{~kg}$ and measuring $0.8 \mathrm{~m} \times 0.6 \mathrm{~m}$.

Upon arrival, the animals were randomly allocated into two groups in holding pens of $13.2 \mathrm{~m}^{2}$ with concrete floors 
and provided with two drinking troughs each. On the day of slaughter, pigs were subjected to two types of pre-slaughter handling along the chute. The animals were conducted through a $0.95 \mathrm{~m}$ wide corridor of concrete slotted floor and $9^{\circ}$ slope. The low-stress group was calmly guided to the stunning place in small sub-groups of 4 animals on average. The animals were not yelled at or touched by materials that could injure them. The handling board was used and the handler was always positioned behind the pigs. Contact with the animals was only allowed by hand touching their flank. The handling proceeded efficiently, with good fluidity and no remarkable interruption. The high-stress group was handled as one single group to the stunning place, causing agitated and stressed behavior as well as a tendency to confront the handler. No handling board was used. Handling was carried out by three handlers: one positioned in front of the animals, a second in their middle and a third right behind the group, responsible for bringing the strayed animals back.

The pigs were slaughtered at a commercial meat packing plant. Slaughter was carried out in accordance with current legislation, according to the Humane Slaughter (Brasil, 2000).

Immediately after the onset of bleeding, blood samples were collected from each animal and sent to a commercial laboratory to measure the levels of cortisol and lactate through the Chemiluminescence and Kinetic Enzymatic techniques, respectively, assessing therewith the physiological stress status.

A sample of $2 \mathrm{~cm}^{2}$ of the semitendinosus muscle was collected 45 minutes after slaughter to assess the R-value, according to the methodology of Honikel and Fischer (1977).

The $\mathrm{pH}$ was measured 45 minutes and 24 hours after slaughter, using a Testo $205 \mathrm{pH}$-meter and inserting it into the longissimus dorsi muscle, between the penultimate and last ribs of the left half of the carcass.

After cooling the carcasses for 24 hours at $2 \pm 2{ }^{\circ} \mathrm{C}$, the 24-hour $\mathrm{pH}$ was measured and the damage score was assessed with the aid of a photographic standard, in which the scores are presented in five categories: (1) no damage, (2) slightly damaged, (3) slightly damaged, (4) moderately damaged, and (5) severely damaged (MLC, 1985).

Between the penultimate and last thoracic vertebrae, from the back to the front, a portion of $10 \mathrm{~cm}$ length of the longissimus dorsi muscle of each left half of carcass was collected and brought to the laboratory.

The tests for R-value, color, drip loss and lipid oxidation (TBARS) were carried out 24 hours after slaughter, whereas the remaining samples were stored in plastic bags and frozen for later shear force testing.
The color was tested using a Minolta $^{\circledR}$ portable colorimeter (model CR-10 colorimeter with illuminant C and $8^{\circ}$ angle of inclination - Tokyo, JP) and the components $L^{*}$ (lightness), $a^{*}$ (red-green component) and $b^{*}$ (yellowblue component) were determined in accordance with the CIELAB system.

The drip loss was determined according to the technique described by Boccard et al. (1981).

For the assessment of lipid oxidation, the thiobarbituric acid reactive substances (TBARS) method was used, according to Pikul et al. (1989).

The samples were classified as normal, PSE (pale, soft, exsudative), DFD (dark, firm, dry) or RN (Napoleon Yield Meat or acid) using the methodologies proposed by Warner et al. (1997) and Channon et al. (2000), cited by Bridi and Silva (2009).

According to methodology proposed by Bridi and Silva (2009) to verify the liquid loss, the frozen samples were weighed and stored in a refrigerator for 24 hours at $4{ }^{\circ} \mathrm{C}$. The samples were then weighed again to obtain the liquid loss at defrosting. After that, they were baked in a preheated electric oven at $180^{\circ} \mathrm{C}$ until reaching an internal temperature of $72{ }^{\circ} \mathrm{C}$, and then stored again for 24 hours at $4{ }^{\circ} \mathrm{C}$. The final weight of the samples was assessed and the liquid loss from cooking was calculated.

The shear force was evaluated as described by Whipple et al. (1990).

The results were evaluated by analysis of variance and the means were compared by Tukey's test, using the SAEG software (Sistema de Análises Estatísticas e Genéticas, version 9.1).

\section{Results and Discussion}

Pigs handled with low stress at pre-slaughter had lower levels of cortisol, lactate and R-value and their carcasses presented higher initial $\mathrm{pH}$ compared with those subjected to high stress (Table 1).

Table 1 - Means and coefficients of variation observed for cortisol, lactate, initial $\mathrm{pH}$, final $\mathrm{pH}$ and $\mathrm{R}$-value in pigs handled with low or high level of stress pre-slaughter

\begin{tabular}{lcccc}
\hline & Low stress & High stress & Significance & CV (\%) \\
\hline Cortisol $(\mathrm{mg} / \mathrm{dL})$ & $6.55 \mathrm{a}$ & $8.58 \mathrm{~b}$ & 0.011 & 32.803 \\
Lactate $(\mathrm{mg} / \mathrm{dL})$ & $12.10 \mathrm{a}$ & $16.12 \mathrm{~b}$ & 0.020 & 28.497 \\
Initial pH & $6.48 \mathrm{a}$ & $6.37 \mathrm{~b}$ & 0.071 & 3.068 \\
Final pH & 5.76 & 5.73 & $\mathrm{NS}$ & 1.534 \\
R-value & $0.87 \mathrm{a}$ & $1.16 \mathrm{~b}$ & 0.001 & 21.529 \\
\hline
\end{tabular}

Different letters in the same row mean significant difference by Tukey's test $(\mathrm{P}<0.10)$.

NS - no significance $(\mathrm{P}>0.10)$; $\mathrm{CV}$ - coefficient of variation. 
These results were similar to those found by Brown et al. (1998) and Warriss and Brown (2000), in which the pigs subjected to high stress had higher levels of cortisol and lactate.

Quantification of serum cortisol has been widely used to assess the level of stress in animals on the farms as well as the stress caused by the pre-slaughter handling (María et al., 2004). The release of cortisol is related to psychological stress, and lactate is related to the physical stress experienced by the animals (Warris et al., 1994).

In the pre-slaughter handling, animals get severely stressed, a condition that leads to increased levels of cortisol and lactate in their bloodstream, and may have as consequence a decrease in the meat quality (D'Eath et al., 2010).

Shaw and Tume (1992) suggested that, when comparing two treatments in terms of stress, the group with the lowest levels of cortisol should be considered the least stressed. Thus, we can conclude that the use of the handling board was effective to minimize the stress of the pigs before slaughter.

Animals subjected to appropriate pre-slaughter conditions to minimize stress have a lower level of serum lactate (Warris and Brow, 2000; Hambrecht et al., 2005; Edwards et al., 2010). In situations of intense physical stress, exhaustion of the muscles can occur and large amounts of lactic acid is formed from the intense degradation of muscle glycogen (Shaw and Tume, 1992).

Lactate values for pigs handled without the board was approximately $25 \%$ higher than in those handled with the board. The animals of both treatments went through identical fasting and resting periods at the slaughterhouse before being slaughtered. Thus, both groups had the same period of time to restore glycogen stocks.

Hence, we can conclude that the main effect responsible for the high level of lactate in animals handled without the board was excessive physical activity performed in the moments before the slaughter, a result similar to that found by Henckel et al. (2002).

The initial $\mathrm{pH}$ of pigs handled without the board was lower than that of the group handled with the board, which is similar to the results obtained by Ludtke et al. (2010).

In stressful conditions, the autonomous sympathetic nervous system releases catecholamines (noradrenalin and adrenalin), substances responsible for triggering the active response mechanism and promoting a physiological status known as "fight or flight". This response is due to the motor cells receiving excitatory action potentials, which stimulates the voltage-gated calcium channels to open up and increase the calcium concentration in the sarcoplasm (Spinosa, 2006).
The sudden increase of calcium ions in the sarcoplasm increases the speed of both utilization of the muscle ATP (adenosine triphosphate) and the glycogenolysis postmortem, resulting in accelerated rates of decline in muscle pH (Rübensam, 2000).

In the living animal, the muscle reserves of phosphocreatine and glycogen are consumed through the Glycolytic Pathway Embden-Meyerhof for the production of pyruvic acid (aerobic pathway) in order to generate energy and keep the metabolism active (Roça, 2012a). When the animal is slaughtered, the supply of oxygen ceases and the production of ATP (energy) turns to come from anaerobic degradation of muscular phosphocreatine and glycogen in an attempt to maintain muscle contraction (Gollnick and Hermansen, 1973).

As a consequence of anaerobic degradation of energy sources, high concentrations of lactic acid in the muscle are verified, since, with the absence of blood flow, lactate can no longer be transported to the liver to be metabolized and converted into glucose through gluconeogenesis (Bassan et al., 2011).

According to Henckel et al. (2000), considering the metabolic changes that occur in stressed animals, the initial $\mathrm{pH}$ will be lower when compared with non-stressed animals and the rate of $\mathrm{pH}$ drop may increase by two to four times, sometimes reaching values below 6.0 in the following hour.

The R-value allows us to measure ATP depletion after slaughter and estimate the onset of rigor mortis. In this paper, the R-value of the group handled without the handling board was higher than that of the group handled with the board (Table 1).

Because the IMP (inosine monophosphate)/ATP ratio for animals handled without the board was greater than one, the concentration of IMP $(250 \mathrm{~nm})$ is greater than the concentration of ATP $(260 \mathrm{~nm})$. This result suggests that those animals were more stressed (more ATP depleted) and/or expended more energy at the time they were being handled to the stunning place in comparison with the animals that were handled with the board.

According to Honikel and Fischer (1977), the R-value of normal meat varies from 0.8 to 1.05 . A value above 1.05 indicates that the meat may be of the defective PSE or DFD type, depending on the initial $\mathrm{pH}$.

It was found that the extent of carcass damage (Table 2) was greater for most stressed pigs, indicating a higher level of stress for this group, since this parameter can also be characterized by visual assessment methods, such as the incidence of lesions (Ludtke et al., 2006). 
Table 2 - Means and coefficients of variation observed for carcass damage scores in pigs handled with low or high level of stress pre-slaughter

\begin{tabular}{lcccc}
\hline & Low stress & High stress & Significance & CV (\%) \\
\cline { 2 - 5 } Damage score & $1.95 \mathrm{a}$ & $2.32 \mathrm{~b}$ & 0.064 & 11.683 \\
\hline
\end{tabular}

Different letters in the same row mean significant difference by Tukey's test $(\mathrm{P}<0.10)$.

NS - no significance $(\mathrm{P}>0.10)$; $\mathrm{CV}$ - coefficient of variation.

During conduction to stunning, animals are often dramatically stressed, due to a too quick and violent handling. Animals react through vocalizations, gathering behavior, and attempts to escape. Handlers, in consequence, usually interfere physically on their back or by yelling (Chevillon, 2000). In this study, due to such behaviors, from both handlers and animals, it was possible to visually notice higher carcass damage in the highly stressed group.

Ludtke et al. (2010) found that $12 \%$ of the animals handled with low stress levels, through the use of a handling board, presented no type of carcass damage, against $42 \%$ of the animals handled in a higher stress manner, through the use of an electric prod. This indicates that low-stress handling is more efficient and reduces the occurrence of carcass damage.

No PSE or DFD anomalies were observed in the group handled under high stress conditions.

The drip loss was not statistically significant between the treatments (Table 3 ).

High concentrations of lactate in hot carcass due to stressful pre-slaughter handling cause a sharp drop in $\mathrm{pH}$ and induce protein denaturation, resulting in loss of the water-retention capacity (Immonen et al., 2000). According to Lawson (2004), the effect of the lower water-retention capacity is reflected in higher liquid losses at defrosting and cooking.

Opposite results were found in this study and the correlation between lactate, $\mathrm{pH}$, and drip loss can explain the data, because the greater amount of lactate in the less

Table 3 - Means and coefficients of variation observed for drip loss (DL), liquid loss from defrosting (LLD), liquid loss from cooking (LLC), shear force (SF) and lipid oxidation (TBARS 24h) in meat of pigs handled with low or high level of stress pre-slaughter

\begin{tabular}{lcccc}
\hline & Low stress & High stress & Significance & CV (\%) \\
\hline DL (\%) & 0.89 & 0.89 & NS & 45.872 \\
LLD (\%) & 7.12 & 7.07 & NS & 23.695 \\
LLC (\%) & 30.42 & 30.53 & NS & 16.478 \\
SF (kgf) & 3.21 & 3.11 & NS & 12.821 \\
TBARS 24h* & 0.40 & 0.38 & NS & 23.161
\end{tabular}

Different letters in the same row mean significant difference by Tukey's test $(\mathrm{P}<0.10)$.

NS - no significance $(\mathrm{P}>0.10)$; $\mathrm{CV}$ - coefficient of variation.

* mg of malonaldehyde $/ \mathrm{kg}$ of sample. stressed group was not enough to influence the final $\mathrm{pH}$ of the meat, therefore not affecting the integrity of the muscle proteins and resulting in no statistical difference for drip loss.

It is assumed that the initial $\mathrm{pH}$ of 6.37 was not low enough to cause protein denaturation, as would be the case for PSE meat, which presents initial $\mathrm{pH}$ lower than 5.8. Meat with proper $\mathrm{pH}$ expresses a neutral charge effect, which is responsible for influencing the water-retention capacity, since water molecules possess neutral charge and are polar, which allow them to associate themselves with the reactive groups of electrically charged muscle proteins, preventing the latter to be lost in the form of exudates (Roça, 2012b), and thus not resulting in differences in drip loss and liquid loss at defrosting and cooking.

The $\mathrm{pH}$ influences the loss of liquid, which in turn may have effects on meat tenderness (Roça, 2012a). However, as the final $\mathrm{pH}$ and the liquid loss were not different, the tenderness, as excepted, did not differ between the treatments with low or high levels of stress.

Among the groups of non-stressed and stressed animals handled with low or high levels of stress, no significant difference for lipid oxidation was observed.

Young et al. (2003) found a similar result for TBARS, in which no statistical difference between stressed and nonstressed animals could be observed.

Lipid oxidation is favored at low $\mathrm{pH}$ values (Yasosky et al., 1984). This may explain the absence of difference in lipid oxidation between the treatments, since the final $\mathrm{pH}$ did not differ between stressed and non-stressed animals.

Differences in color parameters (Table 4) between the two groups were expected, because the initial $\mathrm{pH}$, lactate, and R-value differed statistically among themselves and these parameters influence meat color.

However, results similar to those found in this study were also observed by Brown et al. (1998), Correa et al. (2010), and Ludtke et al. (2010) when evaluating color parameters of meat from pigs handled with low or high levels of stress pre-slaughter.

Table 4 - Means and coefficients of variation observed for color parameters in the meat of pigs handled with low or high level of stress pre-slaughter

\begin{tabular}{lcccc}
\hline & Low stress & High stress & Significance & CV $(\%)$ \\
\hline $\mathrm{L}^{*}$ & 55.31 & 54.64 & $\mathrm{NS}$ & 5.098 \\
$\mathrm{a}^{*}$ & 3.97 & 4.39 & $\mathrm{NS}$ & 28.529 \\
$\mathrm{~b}^{*}$ & 10.52 & 10.55 & $\mathrm{NS}$ & 9.953 \\
$\mathrm{c}^{\circ}$ & 11.42 & 11.58 & $\mathrm{NS}$ & 15.871 \\
$\mathrm{~h}^{\circ}$ & 68.92 & 69.24 & $\mathrm{NS}$ & 7.298 \\
\hline
\end{tabular}

Different letters in the same row mean significant difference by Tukey's test $(\mathrm{P}<0.10)$.

NS - no significance $(\mathrm{P}>0.10) ; \mathrm{CV}$ - coefficient of variation.

$L^{*}$ - lightness; $a^{*}$ - red intensity; $b^{*}$ - yellow intensity; $c^{\circ}$ - chroma; $h^{\circ}$ - hue value. 
Rosenvold and Andersen (2003) also found no difference in color parameters in the meat of pigs that underwent intense physical activity before slaughter.

\section{Conclusions}

Low-stress pre-slaughter handling of pigs is efficient in reducing the level of stress and carcass damage, but has no influence on meat quality.

\section{References}

Bassan, J. C.; Román, J. L.; Gonzálvez, A. B. M.; Rocamora, M. T. M. and Garcia, J. A. A. 2011. Ácido láctico: atualização no desporto e no esforço físico. Available at: <http:/www.invesalia.es/descargas/ Publicaciones/Lactato_portugues.pdf $>$. Accessed on: Apr. 16, 2013.

Boccard, R.; Buchter, L.; Casteels, E.; Cosentino, E.; Dransfield, E.; Hoods, D. E.; Joseph, R. L.; MacDouglas, D. B.; Rhodess, D. N.; Schön, I.; Tinbergena, B. J. and Touraille, C. 1981. Procedures for measuring meat quality characteristics in beef production experiments. Report of a working group in the commission of the European communities' (CEC) beef production research programme. Livestock Production Science 8:385-397.

Bonfim, L. M. 2003. Influência do manejo dos animais durante o transporte sobre a qualidade da carne. Available at: $<$ http:// www.rehagro.com.br/siterehagro/publicacao.do?cdnoticia $=510>$. Accessed on: Apr. 15, 2013.

Brasil. Ministério da Agricultura, Pecuária e Abastecimento. 2000. Instrução normativa n. 3, de 17 de janeiro de 2000. Aprovar o regulamento técnico de métodos de insensibilização para o abate humanitário de animais de açougue. Available at: $<$ http:// www.abef.com.br/Legislacoes.php>. Accessed on: Apr. 15, 2013.

Bridi, A. M. and Silva, C. A. 2009. Avaliação da carne suína. 2.ed. Midiograf, Londrina.

Brown, S. N.; Warriss, P. D.; Nute, G. R.; Edwards. J. E. and Knowles, T. G. 1998. Meat quality in pigs subjected to minimal preslaughter stress. Meat Science 49:257-265.

Chevillon, P. 2000. O bem-estar dos suínos durante o pré-abate e no atordoamento. p.152-168. In: Proceedings of the 1st International Virtual Conference on Pork Quality. Embrapa Suínos e Aves, Concórdia.

Correa, J. A.; Torrey, S.; Devillers, N.; Laforest, J. P.; Gonyou, H. W. and Faucitano, L. 2010. Effects of different moving devices at loading on stress response and meat quality in pig. Journal of Animal Science 88:4086-4093.

Costa, M. J. R. P.; Costa e Silva, E. V.; Chiquitelli Neto, M. and Rosa, M. S. 2002. Contribuição dos estudos de comportamento de bovinos para implementação de programas de qualidade de carne. p.71-89. In: Anais do 20 Encontro Anual de Etologia. Sociedade Brasileira de Etologia, Natal.

D'Eath, R. B.; Turner, S. P.; Kurt, E.; Evans, G.; Thölking, L.; Looft, H.; Wimmers, K.; Murani, E.; Klont, R.; Foury, A.; Ison, S. H.; Lawrence, A. B. and Mormède, P. 2010. Pigs' aggressive temperament affects pre-slaughter mixing aggression, stress and meat quality. Animal 4:604-616.

Edwards, L. N.; Grandin, T.; Engle, T. E.; Porter, S. P.; Ritter, M. J.; Sosnicki, A. A. and Anderson, D. B. 2010. Use of exsanguination blood lactate to assess the quality of pre-slaughter pig handling. Meat Science 86:384-390.

Goettems, G. H. 2011. Manejo pré-abate de suínos. Monograph. Universidade Federal do Paraná, Curitiba. Available at: $<$ http:// dspace.c3sl.ufpr.br/dspace/bitstream/handle/1884/29110/LUIZ\%
20HENRIQUE\%20GOETTEMS.pdf? sequence $=1>$. Accessed on: Apr. 29, 2013.

Gollnick, P. D. and Hermansen, L. 1973. Biochemical adaptations to exercise: anaerobic metabolism. Exercise and Sports Sciences Reviews 1:43.

Hambrecht, E.; Eissen, J. J.; Newman, D. J.; Smits, C. H.; Den Hartog, L. A. and Verstegen, M. W. 2005. Negative effects of stress immediately before slaughter on pork quality are aggravated by suboptimal transport and lairage conditions. Journal of Animal Science 83:440-448.

Henckel, P.; Karlsson, A. H.; Oksbjerg, N. and Søholm, P. J. 2000. Control of post mortem $\mathrm{pH}$ decrease in pig muscle: experimental design and testing of animal models. Meat Science 55:131-138.

Henckel, P.; Karlsson, A.; Jensen, M. T.; Oksbjerg, N. and Petersen, J. S. 2002. Metabolic conditions in porcine longissimus muscle immediately pre-slaughter and its influence on peri-and post mortem energy metabolism. Meat Science 62:145-155.

Honikel, K. O. and Fischer, C. 1977. A rapid method for the detection of PSE and DFD porcine muscle. Journal of Food Science 42:1633-1636.

Immonen, K.; Ruusunen, M. and Puolanne, E. 2000. Some effects of residual glycogen concentration on the physical and sensory quality of normal $\mathrm{pH}$ beef. Meat Science 55:33-38.

Kauffman, R. G.; Wachholz, D.; Henderson, D. and Lochner, J. V. 1978. Shrinkage of PSE, normal and DFD hams during transit and processing. Journal of Animal Science 46:1236-1240.

Lawson, M. A. 2004. The role of integrin degradation in post-mortem drip loss in pork. Meat Science 68:559-566.

Ludtke, C. B.; Silveira, E. T. F.; Bertoloni, W.; Andrade, J. C.; Buzelli, M. L. T.; Bressa, L. R. and Soares, G. J. D. 2010. Bem-estar e qualidade de carne de suínos submetidos a diferentes técnicas de manejo pré-abate. Revista Brasileira de Saúde e Produção Animal $11: 231-241$.

Ludtke, C.; Nogueira, C. E. W.; Bertoloni, W.; Costa, O. A. D. and Soares, G. J. D. 2006. O estresse no manejo pré-abate e na qualidade da carne suína. Documentos, n.119. Embrapa Suínos e Aves, Concórdia. Available at: $<$ http://www.google.com.br/url?sa=t\&rct=j\&q=\&esr $\mathrm{c}=\mathrm{s} \&$ frm $=1 \&$ source $=$ web $\& \mathrm{~cd}=1 \&$ ved $=0$ CDQQFjAA\&url $=\mathrm{http} \%$ 3A\%2F\%2Fwww.cnpsa.embrapa.br\%2Fdown.php \%3Ftipo $\% 3 \mathrm{Dp}$ ublicacoes\%26cod publicacao\%3D1014\&ei=IW9tUcrVF4m08Q SMhYHoBQ\&usg=AFQjCNFhArbEKLhAAI8TKnOBn0iaiuaW CQ\&bvm=bv.45175338,d.eWU>. Accessed on: Apr. 16, 2013.

María, G. A.; Villarroel, M.; Chacon, G. and Gebresenbet, G. 2004. Scoring system for evaluating the stress to cattle of commercial loading and unloading. Veterinary Record 54:818-821.

MLC - Meat and Livestock Commission. 1985. Concern at ringside damage in pigs. Meat and Marketing Technical Notes. p.14-16.

Pikul, J.; Leszcynski, D. E. and Kummerow, F. A. 1989. Evaluation of tree modified TBA methods for measuring lipid oxidation in chickens meat. Journal of Agriculture and Food Chemistry 37:1309-1313.

Roça, R. O. 2012a. Modificações post-mortem. Available at: < http://www. fca.unesp.br/Home/Instituicao/Departamentos/Gestaoetecnologia/ Teses/Roca105.pdf>. Accessed on: Apr. 16, 2013.

Roça, R. O. 2012b. Propriedades da carne. Available at: <http://www. fca.unesp.br/Home/Instituicao/Departamentos/Gestaoetecnologia/ Teses/Roca107.pdf>. Accessed on: Apr. 16, 2013.

Rosenvold, K. and Andersen, H. J. 2003. The significance of preslaughter stress and diet on colour and colour stability of pork. Meat Science 63:199-209.

Rübensam, J. M. Transformações post mortem e qualidade da carne suína. 2000. p.89-99. In: Proceedings of the 1st International Virtual Conference on Pork Quality. Embrapa Suínos e Aves, Concórdia. 
Shaw, F. D. and Tume, R. K. 1992. The assessment of pre-slaughter and slaughter treatments of livestock by measurement of plasma constituents - a review of recent work. Meat Science 32:311-329.

Spinosa, H. S. 2006. Farmacologia aplicada à medicina veterinária. Guanabara Koogan, São Paulo.

Warriss, P. D. and Brown, S. N. Bem-estar de suínos e qualidade da carne: uma visão britânica. 2000. p.17-20. In: Proceedings of the 1st International Virtual Conference on Pork Quality. Embrapa Suínos e Aves, Concórdia.

Warriss, P. D.; Brown, S. N.; Adams, S. J. and Corlett, I. K. 1994. Relationships between subjective and objective assessments of stress at slaughter and meat quality in pigs. Meat Science 38:329-340.
Whipple, G.; Koohmaraie, M.; Dikeman, M. E.; Crouse, J. D.; Hunt, M. C. and Klemm, R. D. 1990. Evaluation of attributes that affect longissimus muscle tenderness in Bos taurus and Bos indicus cattle. Journal of Animal Science 68:2716-2728.

Yasosky, J. J.; Aberle, E. D. and Peng, I. C. 1984. Effects of pH and time of grinding on lipid oxidation of fresh ground pork. Journal of Food Science 49:1510-1512.

Young, J. F.; Rosenvold, K.; Stagsted, J.; Steffensen, C. L.; Nielsen, J. H. and Andersen, H. J. 2003. Significance of preslaughter stress and different tissue PUFA Levels on the oxidative status and stability of porcine muscle and meat. Journal of Agriculture and Food Chemistry 51:6877-6881. 